\title{
Combining field methods and numerical modelling to address challenges in characterising discontinuity persistence and intact rock bridges in large open pit slopes
}

\author{
Z. Tuckey Coffey Mining Pty Ltd, Australia \\ D. Stead Department of Earth Sciences, Simon Fraser University, Canada \\ E. Eberhardt Department of Earth and Ocean Sciences, University of British Columbia, Canada
}

\begin{abstract}
Confidence in stability assessments of large rock slopes may be improved by greater understanding the persistence of adverse discontinuities, and the proportion and location of intact rock bridge content within the slope. This paper presents a discussion of the challenges and uncertainty in characterising discontinuity persistence and intact rock bridges, with reference to results from field investigations of open pit slopes at three mines using digital photogrammetry, ground-based LiDAR, and modified 2D window mapping methods. A conceptual numerical model is then devised, where a distinct element numerical code was applied to investigate the influence of rock bridges on brittle rock mass failure and dilation in a model large open pit slope.

Distinction between co-planar or out-of-plane intact rock bridges, and larger 'rock mass bridges' between more persistent discontinuities is considered necessary and the authors suggest that a fracture network engineering approach tailored to large open pits may be helpful for their characterisation. With modified trace mapping procedures, intact rock bridges may be quantified in terms of an intensity parameter $R_{21}$ that describes the total length of inferred rock bridge traces per unit area within a mapping window. An analogous blast-induced damage intensity factor $B_{21}$ is also introduced, that describes the total length of blast-induced fracture traces per unit area in a mapping window. For numerical models, a damage intensity parameter $D_{21}$ is applied, which quantifies the intensity of fracturing that develops inside a modelled slope.
\end{abstract}

\section{Introduction}

Large rock slope failures rarely occur entirely along completely continuous, pre-existing basal sliding surfaces. Even if major pre-existing structures exist, deformation and failure of large slopes in hard rock is more likely to involve a combination of shearing and dilation of pre-existing discontinuities such as joints, with a degree of stress-induced brittle fracturing of intact rock (Sjöberg, 1999). The process of brittle crack initiation, propagation and coalescence is progressive (Eberhardt et al., 2004), and may be characterised by a time-dependent degradation of rock mass strength in localised zones of stress concentration, that may eventually lead to (1) the formation of a continuous sliding surface and (2) the development of kinematic freedom and finally slope failure (Stead et al., 2006).

The potential complexity of slope failure mechanisms increases with the scale of the slope. In open pit mines, inter-ramp or overall slope failure surfaces may have irregular or step-path geometry, involving rupture through several structural domains with different shear strength properties and different local failure mechanisms. McMahon (1979) introduced the step-path simulation method during investigations for the Bougainville open pit mine in Papua New Guinea with the probabilistic STEPSIM code. Later, the probabilistic step-path simulation approach was further developed for a slope optimisation study at Ok Tedi mine, resulting in the STEPSIM4 code (Little et al., 1999; Baczynski, 2000). The STEPSIM code considered that a global slope failure surface could include up to five domains with different shear strength (Figure 1). 


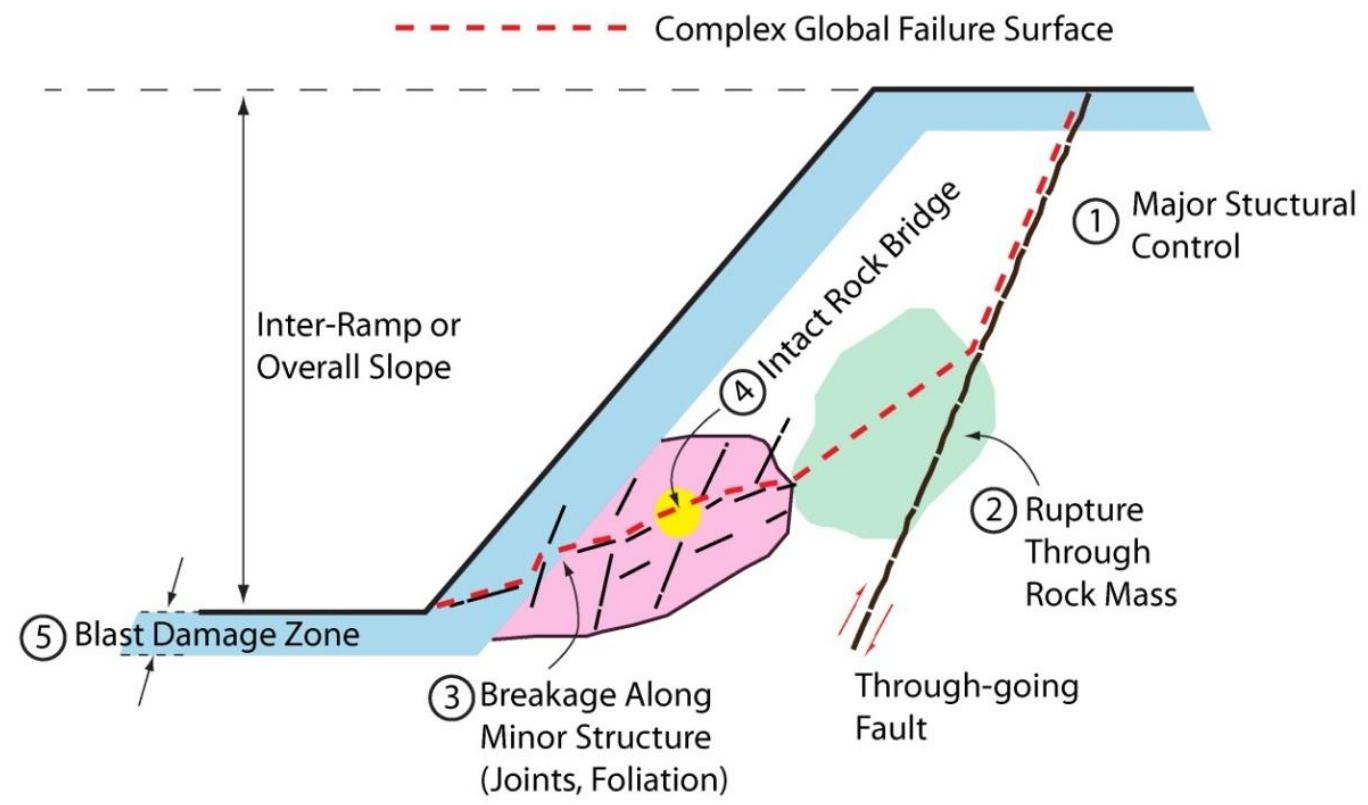

Figure 1 Conceptual illustration of a large scale, complex slope instability with rupture occurring through several different structural domains with different shear strength properties (reproduced from Little, 1999 and Little et al., 1999)

For large slopes in a jointed rock mass, the content of intact rock bridges is an important control on stability, because the shear strength of intact rock bridges may be orders of magnitude greater than the shear strength of discontinuities or of the overall rock mass (Kemeny, 2005). In the case of non-continuous joints forming partial failure surfaces or non-daylighting wedges, the geometry and tensile strength of intact rock bridges, and the persistence of major discontinuity structures are particularly critical factors influencing slope stability (Wesseloo and Dight, 2009).

This paper discusses observations from field investigations at three open pit mines, where special focus was applied to characterisation of discontinuity persistence and intact rock bridges. Discontinuity mapping was carried out at bench, inter-ramp and overall slope scales, using techniques including terrestrial photogrammetry and LiDAR, and also modified 2D window mapping methods. Areal trace intensity was investigated for characterising intact rock bridges and blasting induced damage in bench-scale window maps in what we term a fracture network engineering approach (after Pettitt et al., 2012). The concept of fracture intensity $\left(P_{21}\right)$ was extended to consider intensity of inferred intact rock bridge traces $\left(R_{21}\right)$ and intensity of blasting induced fractures $\left(B_{21}\right)$. Observations from field investigations were used to construct a conceptual numerical model for investigating the role of brittle fracture and dilation in a large open pit slope failure. The results are discussed with reference to key elements of uncertainty in field data collection for characterisation of discontinuity persistence and intact rock bridges in large open pits.

\section{Defining intact rock bridges}

\subsection{Background}

Intact rock bridges are most commonly defined as the intervals of intact rock that exist between the tips of adjacent, non-persistent discontinuities. Jennings (1970) was the first to introduce a mathematical method for incorporating intact rock bridges into slope stability assessment. By considering a theoretical slope failure surface comprising discontinuous joints interrupted by 'patches' of intact rock, Jennings proposed that intact rock bridge content could be represented with a ratio of area (or length, in 2D models) of intact rock bridge patches to total area of the complete failure surface. The proportion of intact rock bridges could then be used to derive equivalent shear strength parameters for the overall failure surface. With the Mohr-Coulomb shear strength criterion, a small intact rock bridge content can significantly increase the 
apparent cohesion along the failure surface. In underground excavations, a rock bridge content of only $1 \%$ has been shown to provide a theoretical tensile load capacity comparable to common underground support systems such as rockbolts and cablebolts (Diederichs, 1999).

Although apparent shear strength methods and limit equilibrium analyses may be well suited to simple coplanar rock bridge cases, more complex rock bridge configurations, as are encountered in fractured rock slopes, may require more sophisticated treatment. Unfortunately, comprehensive delineation of discrete intact rock bridges requires rigorous measurements of all discontinuity locations, persistence and orientations; this is effectively impossible to carry out for an entire pit slope (Figure 2).

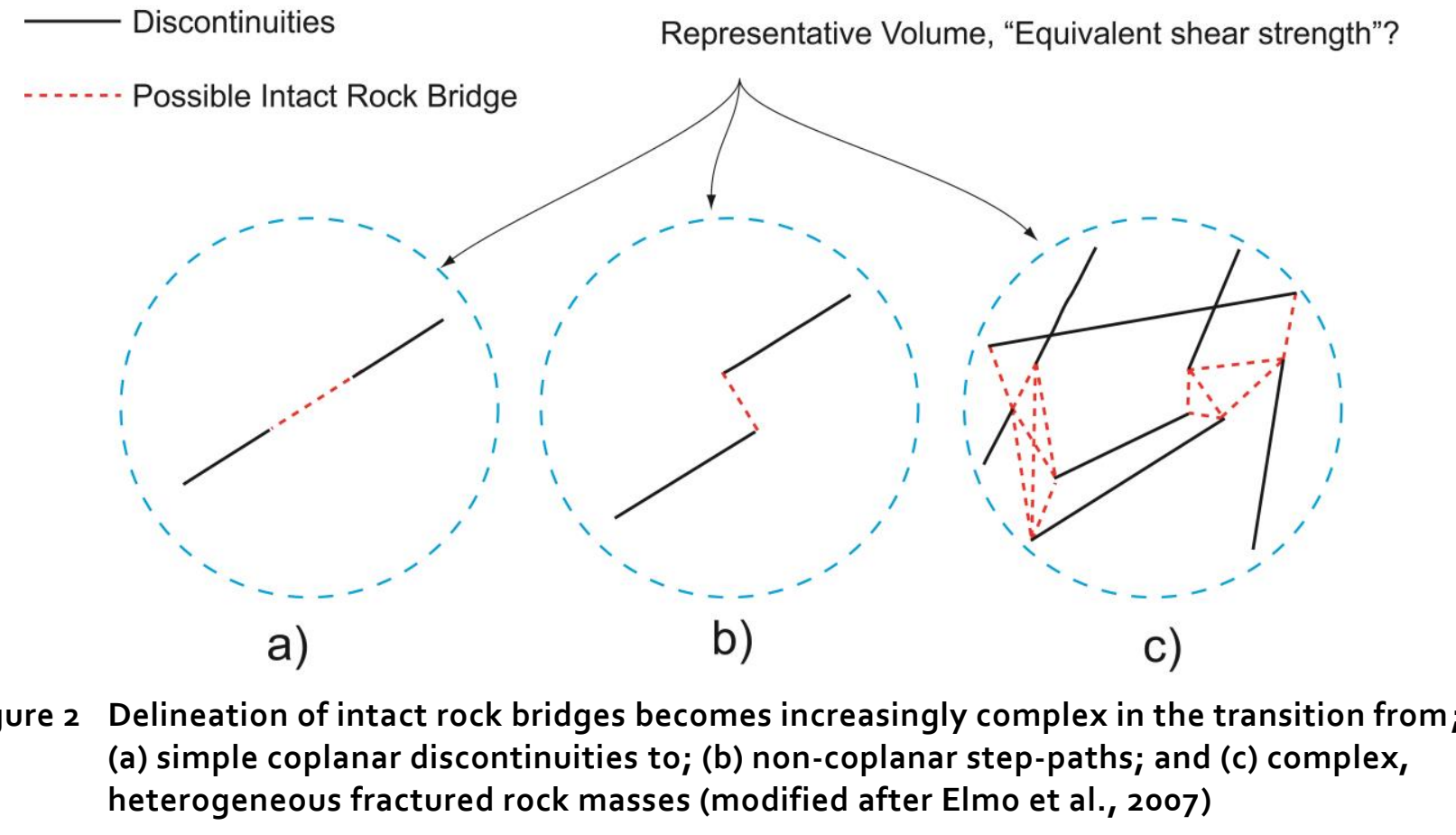

Experimental studies on laboratory scale specimens have shown that rock bridge shear strength is dependent on both loading conditions (i.e. the principal stress magnitudes and orientations) and on the geometry of pre-existing discontinuities (Gehle and Kutter, 2003; Sagong and Bobet, 2002; Wong et al., 2001; Bobet and Einstein, 1998; Lajtai, 1969).

Although data for laboratory scale experiments are available, similar studies of slope failure in field scale rock masses are generally not feasible. Most case studies concerning rock bridges in slope failures comprise forensic investigations of previous failures, where failed intact rock bridges may be identified by the presence of fresh rock or brittle fracture morphology on the failure surface (Table 1).

Numerical modelling and limit equilibrium studies of rock bridge failure in slopes have also been undertaken (Havaej et al., 2012; Hungr and Amman, 2011), however rock bridge modelling studies are often limited to back-analyses and sensitivity analysis, with limited applicability to date for predictive modelling of large open pit slopes. Although research into complex numerical modelling of rock slopes is increasing (Stead and Coggan, 2012), the scarcity of case studies that explicitly quantify intact rock bridges highlights the need for further development of field data collection methods. Improved confidence in predictive modelling of large open pit slopes will require better understanding of the uncertainty of input parameters for persistence and intact rock bridges. A useful initial step may be to develop suggested terminology and measurement techniques for intact rock bridges and discontinuity persistence, specially tailored to large open pits. 
Table 1 Selection of estimated rock bridge contents from published slope stability studies

\begin{tabular}{|c|c|c|c|}
\hline Location & $\begin{array}{l}\text { Measurement } \\
\text { Method }\end{array}$ & $\begin{array}{c}\text { Estimated Rock } \\
\text { Bridge Content (\%) }\end{array}$ & Authors \\
\hline $\begin{array}{l}\text { Palliser slide, } \\
\text { Alberta Canada }\end{array}$ & $\begin{array}{l}\text { Failure mapping; } \\
\text { length } \%\end{array}$ & 2 to 3 & $\begin{array}{l}\text { Sturzenegger and Stead } \\
\text { (2012) }\end{array}$ \\
\hline Åknes slide, Norway & $\begin{array}{l}\text { Failure mapping; } \\
\quad \text { length \% }\end{array}$ & 1 to 3 & Grøneng et al. (2009) \\
\hline $\begin{array}{l}\text { Highway roadcuts, } \\
\text { Idaho USA }\end{array}$ & $\begin{array}{l}\text { Failure mapping; } \\
\text { length \% }\end{array}$ & 0 to 3 & Ristau (1994) \\
\hline $\begin{array}{c}\text { Gypsum Mine, } \\
\text { Arizona USA }\end{array}$ & $\begin{array}{l}\text { Failure mapping; } \\
\text { length } \%\end{array}$ & 16 to 36 & LeBaron (2011) \\
\hline $\begin{array}{c}\text { Diavik A154 Pit, } \\
\text { Northwest Territory } \\
\text { Canada }\end{array}$ & $\begin{array}{l}\text { DFN modelling study; } \\
\text { length \% }\end{array}$ & $\begin{array}{c}>5 \\
25 \\
3 \text { to } 45\end{array}$ & $\begin{array}{l}\text { Karami et al. (2007) } \\
\text { Moffitt et al. (2007) } \\
\text { Elmo et al. (2011) }\end{array}$ \\
\hline $\begin{array}{l}\text { Rockfall Scars, } \\
\text { French Sub-Alps }\end{array}$ & $\begin{array}{l}\text { Failure mapping; } \\
\text { area } \%\end{array}$ & 0.2 to 5.0 & $\begin{array}{l}\text { Frayssines and Hantz } \\
\qquad(2006)\end{array}$ \\
\hline $\begin{array}{l}\text { Failed overhang road } \\
\text { half-tunnel, Italy }\end{array}$ & $\begin{array}{l}\text { Failure mapping; } \\
\text { area } \%\end{array}$ & 26 & $\begin{array}{c}\text { Paronuzzi and Serafini } \\
\text { (2009) }\end{array}$ \\
\hline $\begin{array}{l}\text { Natural slope failure, } \\
\text { Western Alps, France }\end{array}$ & $\begin{array}{l}\text { Failure mapping; area \% } \\
\text { + numerical simulation }\end{array}$ & 7.3 & Lévy et al. (2010) \\
\hline $\begin{array}{l}\text { Randa rockslide, } \\
\text { Switzerland }\end{array}$ & $\begin{array}{l}\text { Length \% for specific } \\
\text { discontinuity sets, } \\
\text { + numerical simulation }\end{array}$ & 8 to 45 & Gischig et al. (2011) \\
\hline
\end{tabular}

\subsection{Coplanar rock bridges and proto joints}

Discontinuities in a rock mass range in size from sub-millimetre microcracks to kilometre scale faults. Even ostensibly 'intact rock' free of any visible discontinuities may contain a pervasive microfabric comprising systematic grain-scale cracks induced by geological processes such as cooling, uplift, exhumation, glaciation, or tectonic compression (Gudmundsson, 2011). Microscopic studies of intact plutonic granite have shown that distinct sets of intra- and inter-granular microcracks occur parallel to the three orthogonal axes of preferential splitting exploited in quarry excavations: rift, grain, and hardway (Fuji et al., 2007).

In an investigation of sheet jointing in granites, Hencher et al. (2011) proposed that progressive extension and coalescence of tensile microcracks may eventually result in the formation of persistent mechanical discontinuity planes. During intermediate stages of joint formation, planar structures comprising partially-coalesced microcracks may form incipient 'proto joints' that are interrupted by intact rock bridges, contributing cohesion and tensile strength to the discontinuity. The proto joint theory closely resembles the conceptual 'patch' model for rock bridges proposed by Jennings (1970). Joint formation by propagation and coalescence of microcracks may be a slow process - a sub-critical analogue to the micromechanical model for rock damage described by Diederichs (2007), who asserted that failure of strong, brittle rocks is controlled by the initiation of independent tensile cracks that, under confinement, may eventually interact and form macroscopic shearing structures.

\subsection{Out-of-plane rock bridges and DFN techniques}

Out-of-plane rock bridges may be defined as the 3D space between the tips of non-coplanar discontinuities with different orientations, belonging to different joint sets. In contrast to coplanar rock bridges, which 
represent in-plane 'patches' contributing added shear strength to individual proto joints, out-of plane rock bridges may have non-systematic 3D geometry, and thus they contribute cohesion and tensile strength to the overall volume of rock mass.

Due to the 3D structure of out-of-plane rock bridges, the results of 2D window mapping interpretations, as collected during open pit bench face mapping, are subject to the same orientation bias that occurs in any standard joint survey (Terzaghi, 1965). Figure 3 further illustrates the dependence of 2D rock bridge mapping on window location: three parallel mapping windows offset by a small distance result in markedly different 2D interpretations of rock bridge configurations. Notably, it is impossible to distinguish between coplanar 'patch' type rock bridges and the larger 3D rock bridge based on the results of a single 2D bench face map. This conceptual illustration highlights the practical importance of window mapping in multiple locations with different slope orientations.

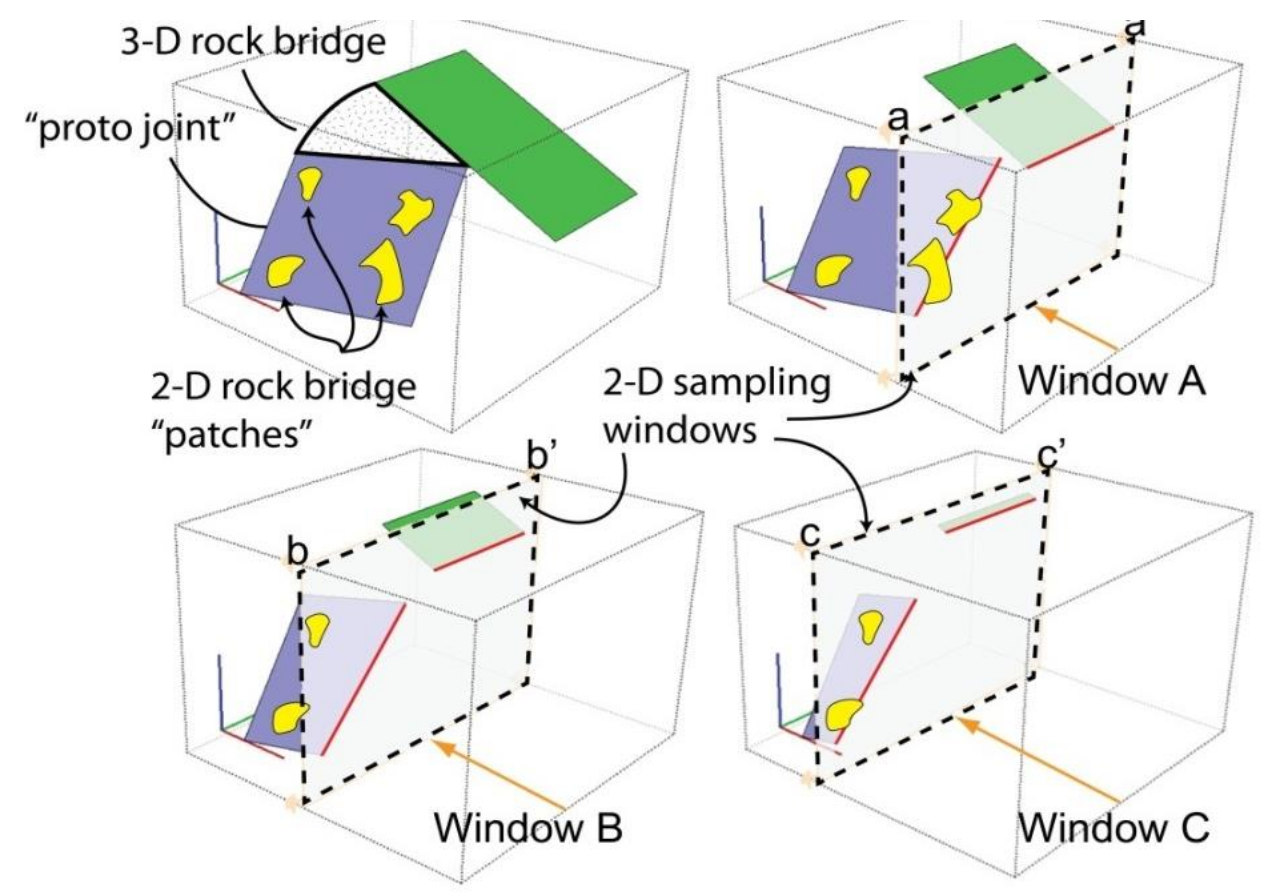

Figure 3 Influence of $2 D$ trace mapping from three locations $\left(A ; B\right.$; and $C$ ) on a ${ }_{3} D$ discrete fracture network with intact rock bridges

Discrete fracture network (DFN) methods are capable of representing out-of-plane rock bridges explicitly, by generating a stochastic model of fracture locations, sizes and orientations. The numerical modelling technique of embedding a DFN into a bonded assembly of distinct elements, or into a hybrid finite-discrete element code, is called the synthetic rock mass (SRM) method (Mas Ivars et al., 2011). Recent research has shown that the SRM technique can be successfully used to simulate shear strength tests of representative volumes of rock mass (length dimensions in the order of $100 \mathrm{~m}$ ); the results of SRM tests can be used to derive equivalent material parameters for input into pit scale models constructed with continuum codes such as FLAC3D (Sainsbury et al., 2008).

For large open pit slopes in strong, jointed rock masses where complex failure mechanisms are possible, out-of-plane rock bridges may be more critical than coplanar rock bridges in influencing stability. Stead et al. (2007) concluded that three dimensional characterisation of rock bridge geometry is critical for non-conservative brittle fracture simulation in open pit slopes. Field techniques must focus therefore on limiting the influence of orientation bias, by sampling wherever possible from exposures at different orientations and in multiple locations. 


\section{Defining discontinuity persistence}

\subsection{Trace length, surface area and discontinuity shape}

Persistence describes discontinuity size, and guidelines for categorising persistence are based on the length of discontinuity traces measured in mapping windows or along scanlines (ISRM, 1978). Conceptual models for rock joints usually consider idealised elliptical or square discontinuity shapes, however fractography studies have shown that many different and potentially irregular discontinuity shapes are possible, depending on fracture formation mechanisms and interaction between adjacent discontinuities during propagation (Bahat et al., 2005). Assessments of discontinuity persistence should therefore include a fractographic interpretation of discontinuity genesis, shape and surface morphology as well as termination.

A major obstacle in field measurement of persistence is the uncertainty in the estimation of the full size of planar discontinuity exposures or linear traces. F-bias describes the error in measured trace length based on the theory that discontinuity traces in outcrop occur as random chords through elliptical discontinuities which intersect the exposure; therefore (Priest, 2004). Therefore, due to f-bias, true persistence will almost always be greater than the apparent $2 \mathrm{D}$ trace length measured with conventional field mapping methods. Similarly, the lengths of step-path segments observed in outcrop will always be smaller than the true persistence of the discontinuities that form the step-paths (Figure 4).
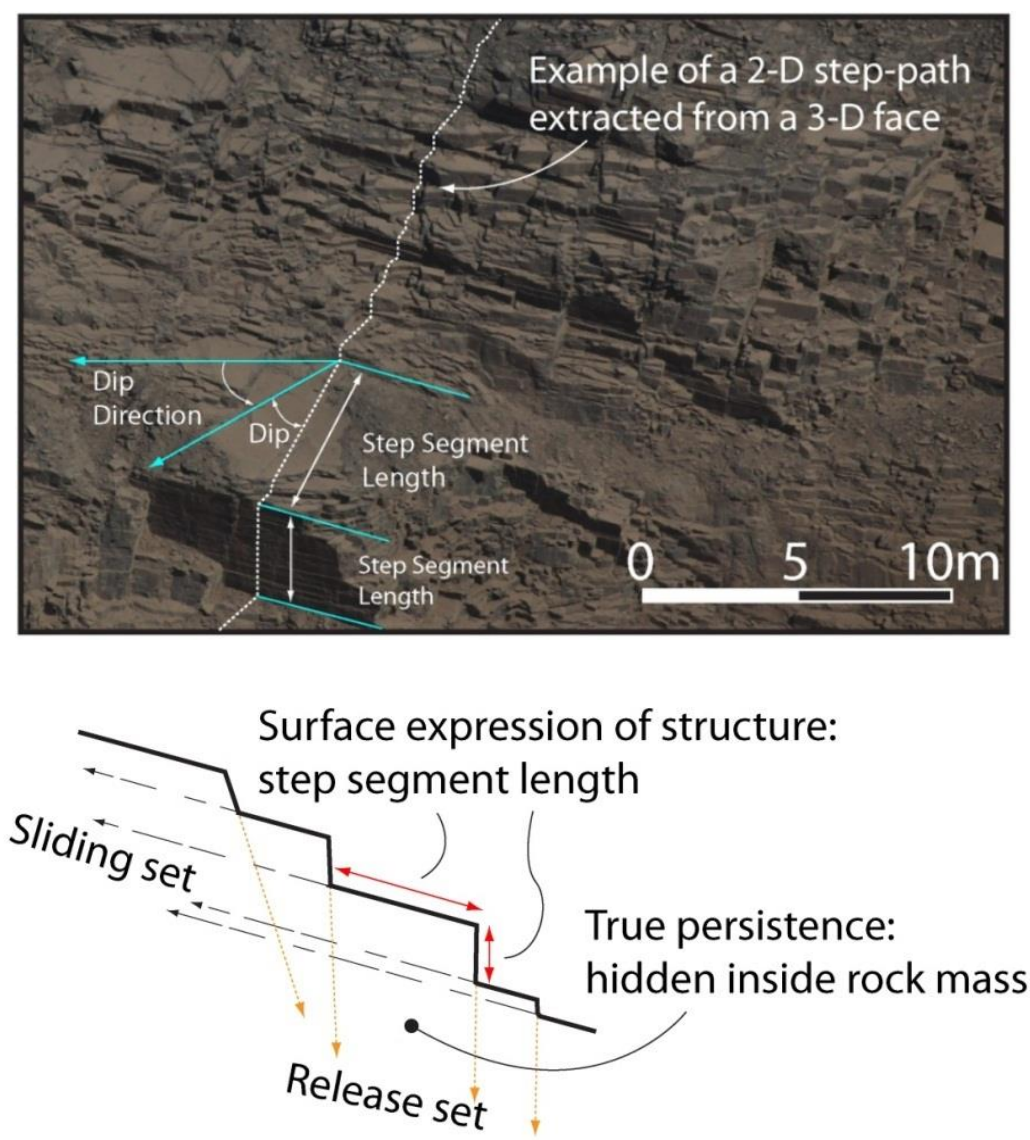

Figure 4 Surface expression of step path structures represent a lower bound estimate of persistence, because the discontinuities forming the steps extend inside the rock mass

\subsection{Termination style, fracture intersections and connectivity}

Termination style describes the condition of discontinuity tips, and relates to intact rock bridge content and fracture connectivity. Two main types of termination are recognised: (1) termination in intact rock; and (2) termination against other discontinuities. If a large proportion of discontinuities terminate in intact rock, then we may infer the existence of intact rock bridges (either planar or out-of-plane). Conversely, frequent 
termination against other discontinuities from different joint sets would suggest an interconnected fracture network containing less intact rock bridges (Ozkaya and Mattner, 2003).

Laboratory simulations and field mapping investigations of open pit slopes have indicated that the peak strength and failure mechanism of jointed rock masses depend strongly on termination style (Van Sint Jan and Prudencio, 2008). We suggest that joint sets with frequent termination in intact rock may be considered as 'proto joints' that retain cohesion and tensile strength, and have not fully coalesced into persistent mechanical discontinuities.

\section{$4 \quad$ Field observations from three open pits}

\subsection{Geotechnical overview of study sites}

Field investigations were undertaken at three open pit mines:

- Diavik is a diamond mine in North West Territories (NWT), Canada, comprising two open pits and underground operations; this investigation focused on the A418 pit, which is excavated in strong, moderately fractured granite (GSI > 70) with some 'rafts' of metasedimentary turbidites intruded by kimberlite pipes; the open pits are partially enclosed by a waterproof dyke which retains the water of Lac de Gras (Moffitt et al., 2007).

- Jwaneng mine, located in Botswana, is the richest diamond mine in the world by production value, and the country rock comprises a bedded metasedimentary sequence intruded by kimberlite pipes (Tunono et al., 2011); this investigation focused on the east wall, where bedding dips into the pit, at 20 to $30^{\circ}$ towards northwest.

- Highland Valley is a porphyry copper mine in BC, Canada; this investigation focused on the Upper West Wall of the main Valley pit, which comprises highly fractured and hydrothermally altered granodiorite; previous investigations of major, slow-moving slope instabilities at the Highland Valley Lornex pit have shown that weaker zones of rock mass may undergo significant internal deformations (Tosney et al., 2004).

Due to differences in rock mass structure, the pit slopes at each mine are characterised by different potential failure mechanisms (Figure 5). Diavik is the most massive and most sparsely fractured rock mass of the three sites: the rock mass comprises strong moderately fractured massive granite, and mapping with photogrammetry confirmed the frequent occurrence of widely-spaced $(>10 \mathrm{~m})$ very high persistence discontinuities (i.e. $>20 \mathrm{~m}$, ISRM, 1978) with several multi-bench scale structures with persistence exceeding $100 \mathrm{~m}$ (Figure 5(b)). Observed bench-scale instabilities mostly comprise wedge failures, and are controlled by the persistence and orientation of adversely oriented joints, and by the strength of in-plane and out-of-plane intact rock bridges.

Jwaneng is the only site with a layered (anisotropic) rock mass. Photogrammetry and mapping show that the northwest-dipping foliation is the dominant influence on instability, with bedding thicknesses (and corresponding step path heights) ranging from about $10 \mathrm{~cm}$ to $4 \mathrm{~m}$. The existing slopes resemble 3D step-paths that have resulted from overbreak and progressive failure of nested pentahedral wedges (Figure 5(c)).

Highland Valley is the most intensely fractured rock mass of all three sites: multiple phases of tectonic damage and hydrothermal fluid infiltration (and associated natural hydraulic fracturing) have produced a stockwork type fracture network that is superimposed over older joint sets. The intact rock is locally highly altered and weak, proximal to major fracture zones. Field mapping and LiDAR indicated that the rock mass comprises small block sizes typically on the order of $1 \mathrm{~m}^{3}$ and instability is characterised by progressive bench-scale sliding failures that result in crest back-break and loss of rockfall catching capacity (Figure 5(a)). 


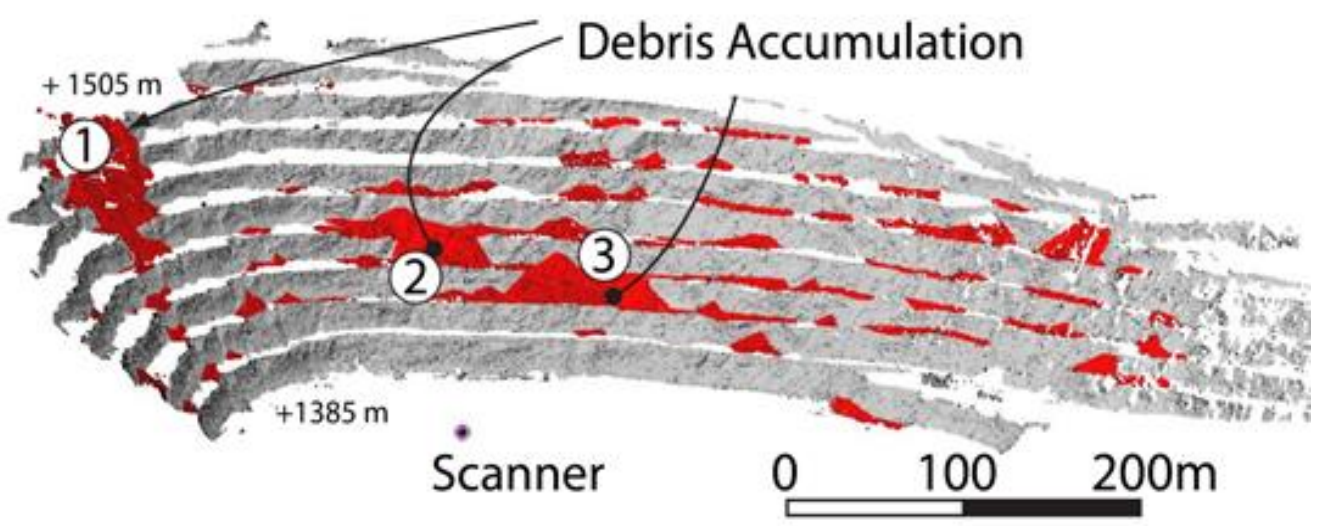

(a)

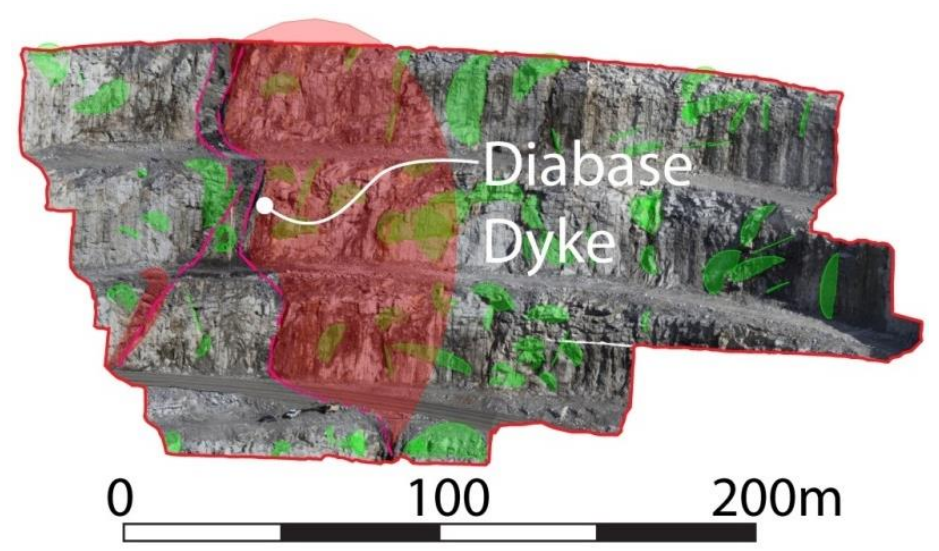

(b)

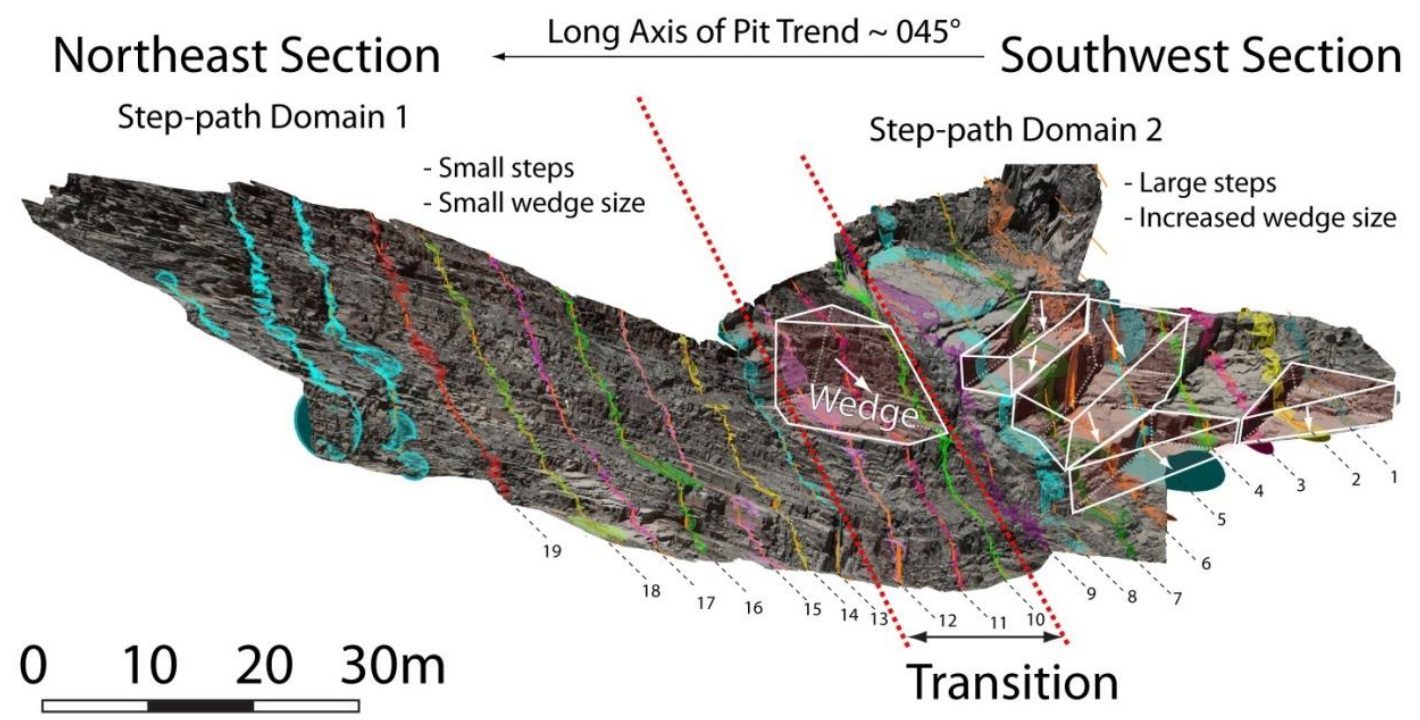

(c)

Figure 5 Typical slopes at the three case study mines. (a) LiDAR point cloud of Highland Valley Upper West wall highlighting minor failed debris; (b) partial photogrammetry fan model of Diavik A418 pit ( $f=200 \mathrm{~mm}$; distance $=400 \mathrm{~m}$ ) highlighting high persistence structures; (c) partial photogrammetry model of Jwaneng East wall $(f=100 \mathrm{~mm}$; distance $=50 \mathrm{~m}$ ) showing a step-path characterisation approach for evaluating existing slope geometry 
Although it is difficult to assign a precise number to intact rock bridge content, a simplified preliminary assessment of the structural geology at each site can provide a helpful basis for understanding the chronology and mechanisms of fracture network development, we may infer qualitatively the roles of discontinuity persistence and intact rock bridges in influencing slope stability (Figure 6).

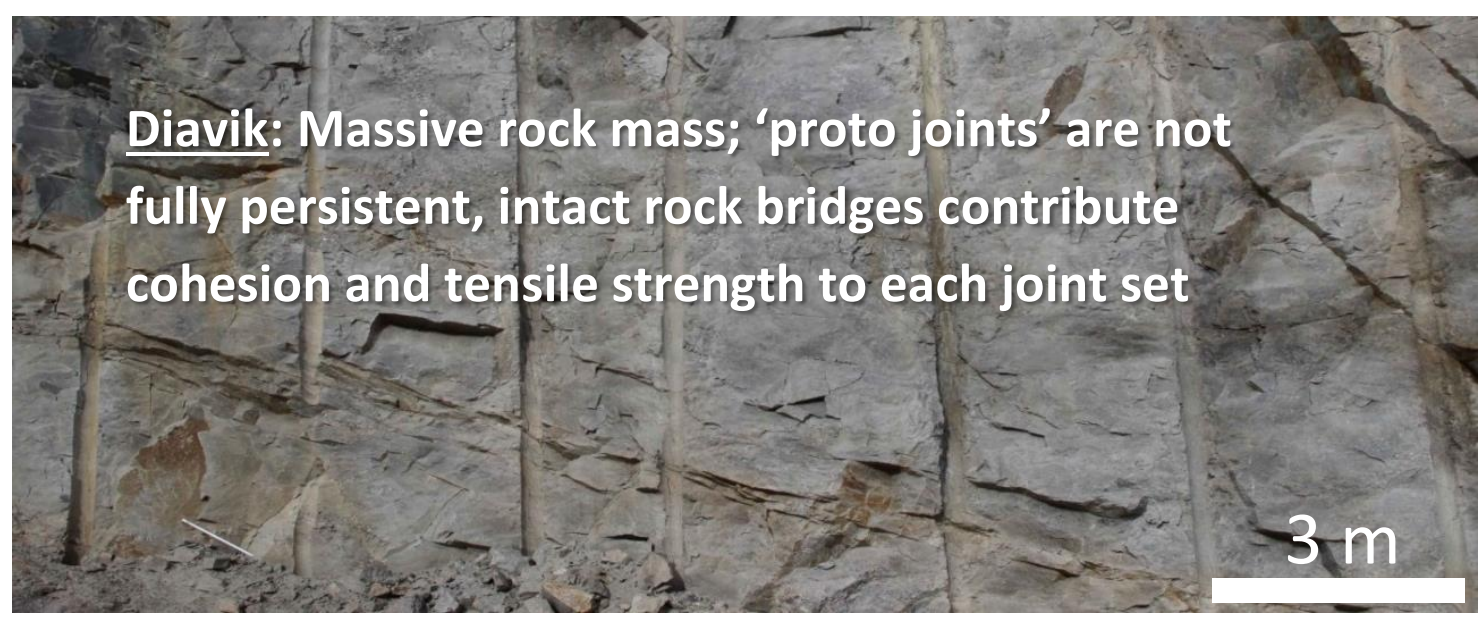

(a)

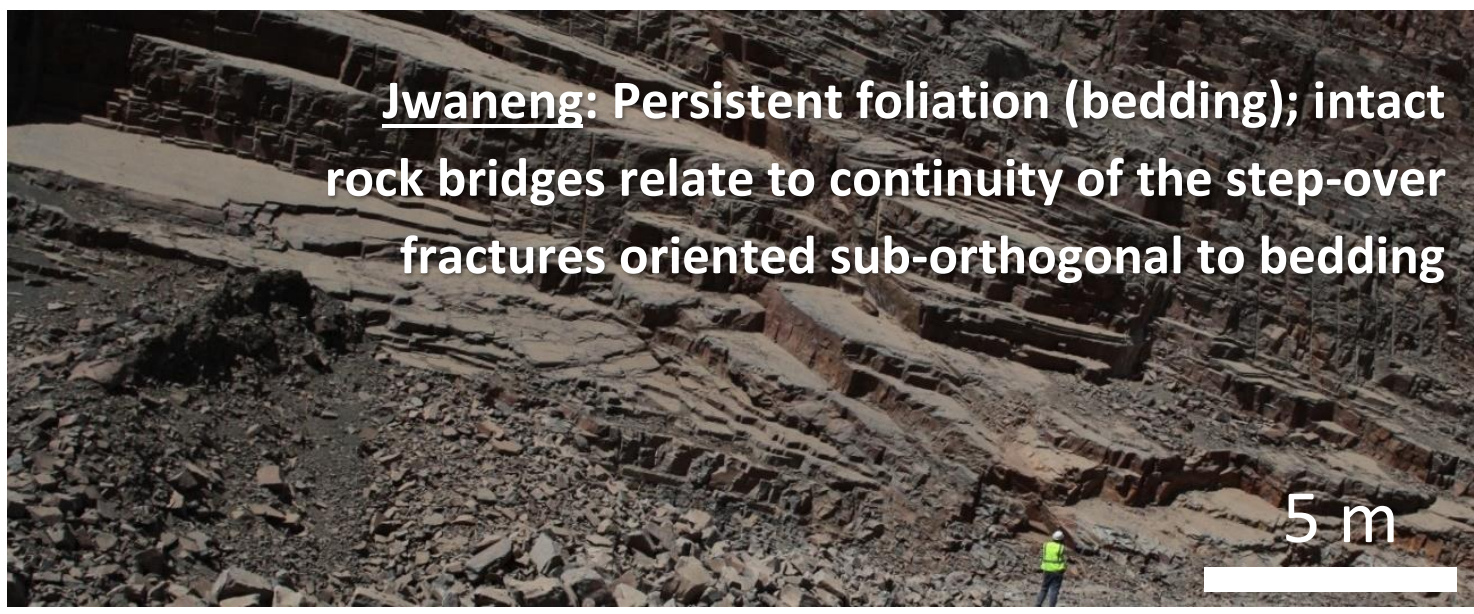

(b)

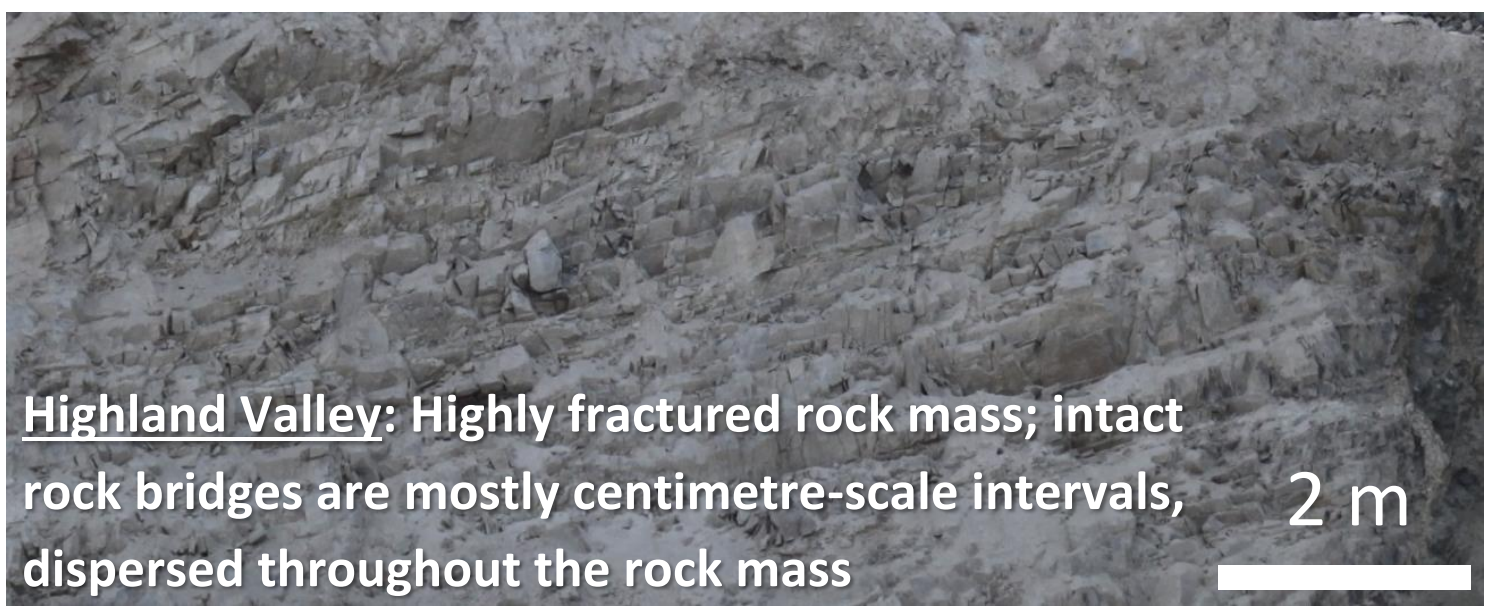

(c)

Figure 6 Typical rock masses for three mines, showing different fracture network characteristics including major differences in persistence and the nature of intact rock bridges 
At Diavik the major joint sets resemble incipient 'proto joints', showing evidence of in-plane rock bridges. Further investigation of specific discontinuity sets could be used to justify the assumption of true cohesion and tensile strength for specific joint sets showing evidence of intact rock bridges. Major 'rock mass bridges' of fractured rock mass, existing between extremely persistent (i.e. $100 \mathrm{~m}+$ ) structures, may be important considerations for inter-ramp or overall slope scale stability.

The layered rock mass at Jwaneng is characterised by effectively 'fully persistent' bedding; intact rock bridges are likely to be critical to the formation of step-path fractures, and the size of out-of-plane intact rock bridges may be related to bedding spacing (layer thickness). At Highland Valley the highly fractured $(\mathrm{GSI}<45)$ rock mass contains discontinuities including recent brittle fractures down to the centimetre scale; out-of-plane intact rock bridges are likely to occur as millimetre to centimetre-scale intervals, dispersed throughout the volume of fractured rock mass.

\subsection{Window mapping results}

Bench face window maps at Diavik and Jwaneng were constructed at two different sizes: the windows at Jwaneng are limited to $6 \mathrm{~m}$ long and $2 \mathrm{~m}$ high (i.e. within reach for physical field mapping), while those at Diavik are larger, up to approximately $20 \mathrm{~m}$ square, covering almost an entire vertical bench face (i.e. $\mathrm{L}=20 \mathrm{~m}, \mathrm{H}=20 \mathrm{~m}$, for photographic mapping only).

Based on mapping of the discontinuities in the windows, a fracture intensity approach was applied to characterise pre-existing discontinuities $\left(P_{21}\right)$, intact rock bridges $\left(R_{21}\right)$, as well as recent blast-induced fractures $\left(B_{21}\right)$. All three intensity parameters consider areal intensity, which is defined as the sum of trace length divided by window surface area. Thus, $\mathrm{P}_{21}$ measures the sum length of pre-existing discontinuities, divided by the $2 \mathrm{D}$ window surface area. Similarly, $\mathrm{R}_{21}$ measures the sum length of inferred intact rock bridges, divided by the $2 \mathrm{D}$ window surface area. The blasting intensity parameter $\mathrm{B}_{21}$ measures the sum length of blast induced fractures, also divided by the 2D window surface area.

Inferred intact rock bridges were traced between the nearest tips of pre-existing discontinuities. Blast induced fractured were identified as brittle fracture features that overprint the pre-existing joint sets, such as pre-splitting cracks, and other irregular or non-planar fractures showing evidence of tensile morphology and rapid (dynamic) loading conditions attributable to blasting. Figure 7 illustrates broadly the measurements of fracture intensity $P_{21}$, rock bridge trace intensity $R_{21}$, and blast damage intensity $B_{21}$, plotted against local GSI for the 12 window maps, six from Diavik and six from Jwaneng.

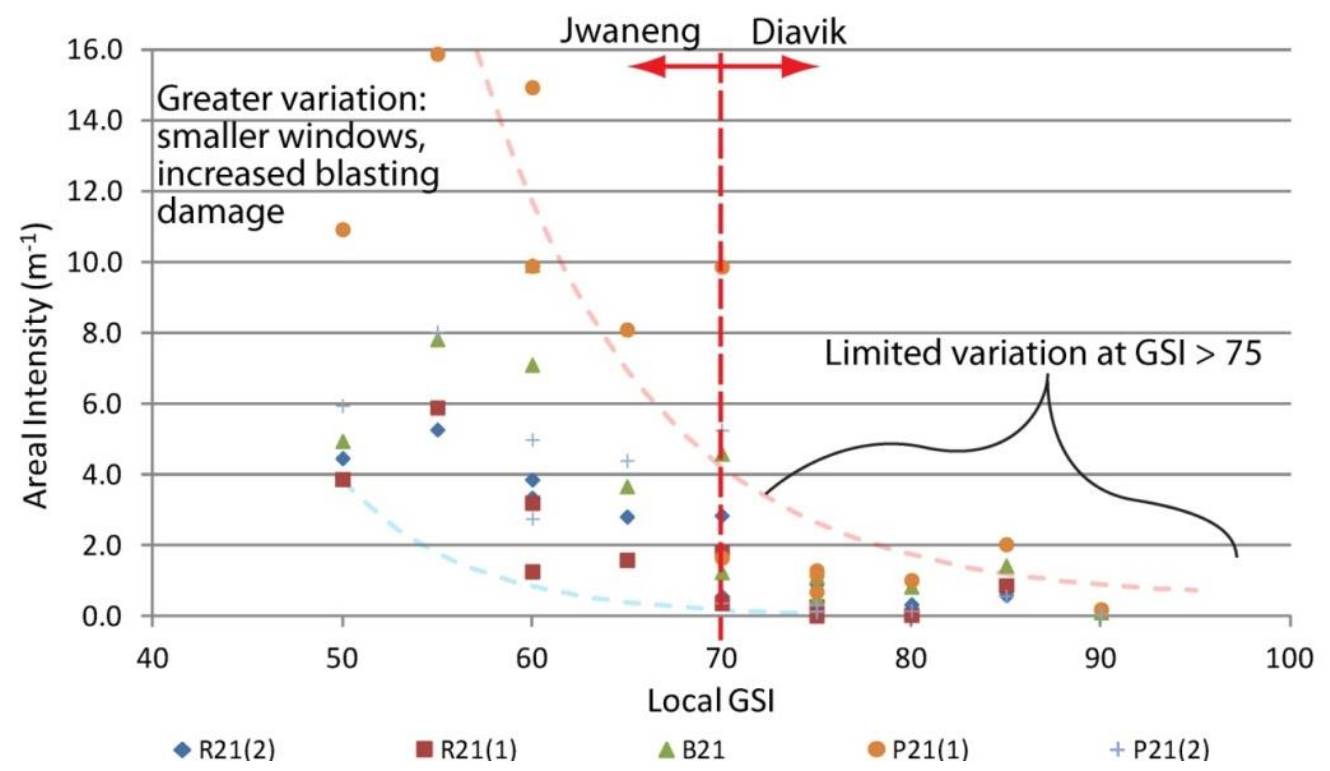

Figure 7 Areal Intensity of intact rock bridge traces (R21); blast-induced damage (B21); and preexisting discontinuities ( $P_{21}$ ) vs rock mass quality for results from Diavik (GSI >70) and Jwaneng $(50<\mathrm{GSI}<70)$ 
The Diavik window maps are larger than the maps from Jwaneng, and the rock mass at Diavik comprises the more massive rock mass of the two, with wider joint spacing. The intensity results from Diavik show the lowest degree of scatter, suggesting a relatively low uncertainty in the configuration of discontinuities, rock bridges, and blasting damage. In contrast, the results from Jwaneng, measured in windows comprising layered, moderately fractured rock mass $(50<\mathrm{GSI}<70)$, show a higher degree of scatter, suggesting higher uncertainty in the intensity of pre-existing discontinuities, blast damage, and intact rock bridges.

The results suggest that increases in GSI may be associated with decreased uncertainty in discontinuity and rock bridge intensity. However, intermediate quality rock masses (GSI $\approx 40$ to 70 ), may result in higher uncertainty. In such moderately jointed rock masses, the orientation, persistence and shear strength of very persistent, adverse 'outlier' discontinuities (i.e. the top $1 \%$ most persistent structures) may be the dominant control on slope stability.

\section{$5 \quad$ Conceptual numerical modelling of rock bridge content}

\subsection{Slope failure requiring dilation}

The field observations from Highland Valley suggest that a highly fractured rock mass may be well suited to an intact rock bridge model which considers out-of-plane rock bridges as dispersed throughout a volume of rock mass, rather than confined to a specific potential failure surface. We suggest that the aggregate quantity of intact rock bridges existing inside a slope could be called the 'volumetric rock bridge content'. In order to investigate the influence of volumetric rock bridge content, a conceptual slope model was constructed, where internal dilation of the slope must occur in order for kinematic freedom to develop.

The Prandtl wedge transition zone concept has traditionally been applied in geotechnical engineering for analysis of bearing capacity failures in soil, but has also been proposed as a mechanism allowing kinematic freedom to develop through internal dilation in large landslides; Mencl (1966) first suggested the Prandtl wedge as a possible explanation of the failure mechanism of the Vaiont slide in Italy.

Depending on the joint pattern geometry and termination conditions, the volumetric rock bridge content inside the slope may be expected to influence the shear strength and stiffness of the potentially unstable volume. Greater content of rock mass bridges (large scale bridges which are assigned rock mass shear strength) should result in greater resistance to shearing and dilation, whereas a model with no rock mass bridges (i.e. comprising fully-formed, discrete blocks) may accommodate shearing more easily. For this model, a random Voronoi tessellation was used to represent the fracture network, simulating an effectively homogeneous fractured rock mass (Figure 8).

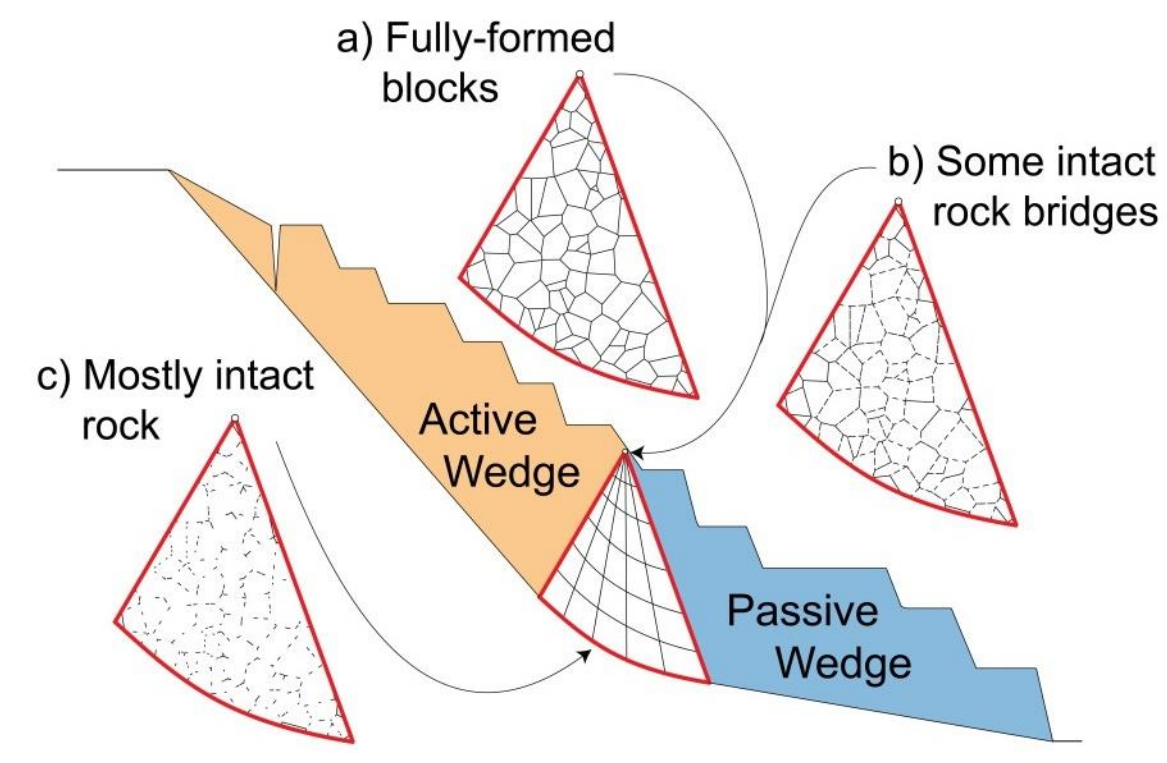

Figure 8 Three conceptual rock masses with different initial content of rock mass bridges 


\subsection{Preliminary distinct element method trial}

Five different cases in a slope model were constructed (Case A to Case E) using the distinct element code UDEC (Itasca, 2010). The Voronoi tessellation function was used to represent a rock mass comprising blocks with edge lengths of approximately $10 \mathrm{~m}$. Rock mass strength (cohesion and tensile strength) properties were assigned to Voronoi polygon boundaries (Figure 9 shows selected examples, with model setup and results for Case $A, B$ and $E$ ).

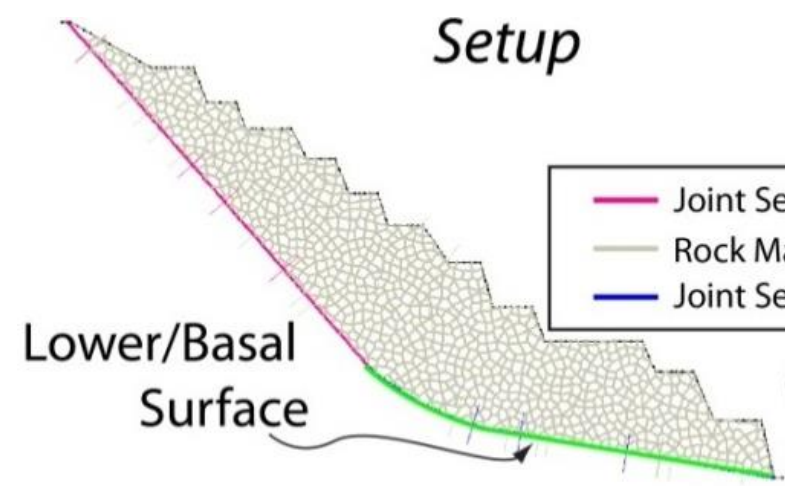

\section{Case A \\ $100 \%$ rock mass bridges}
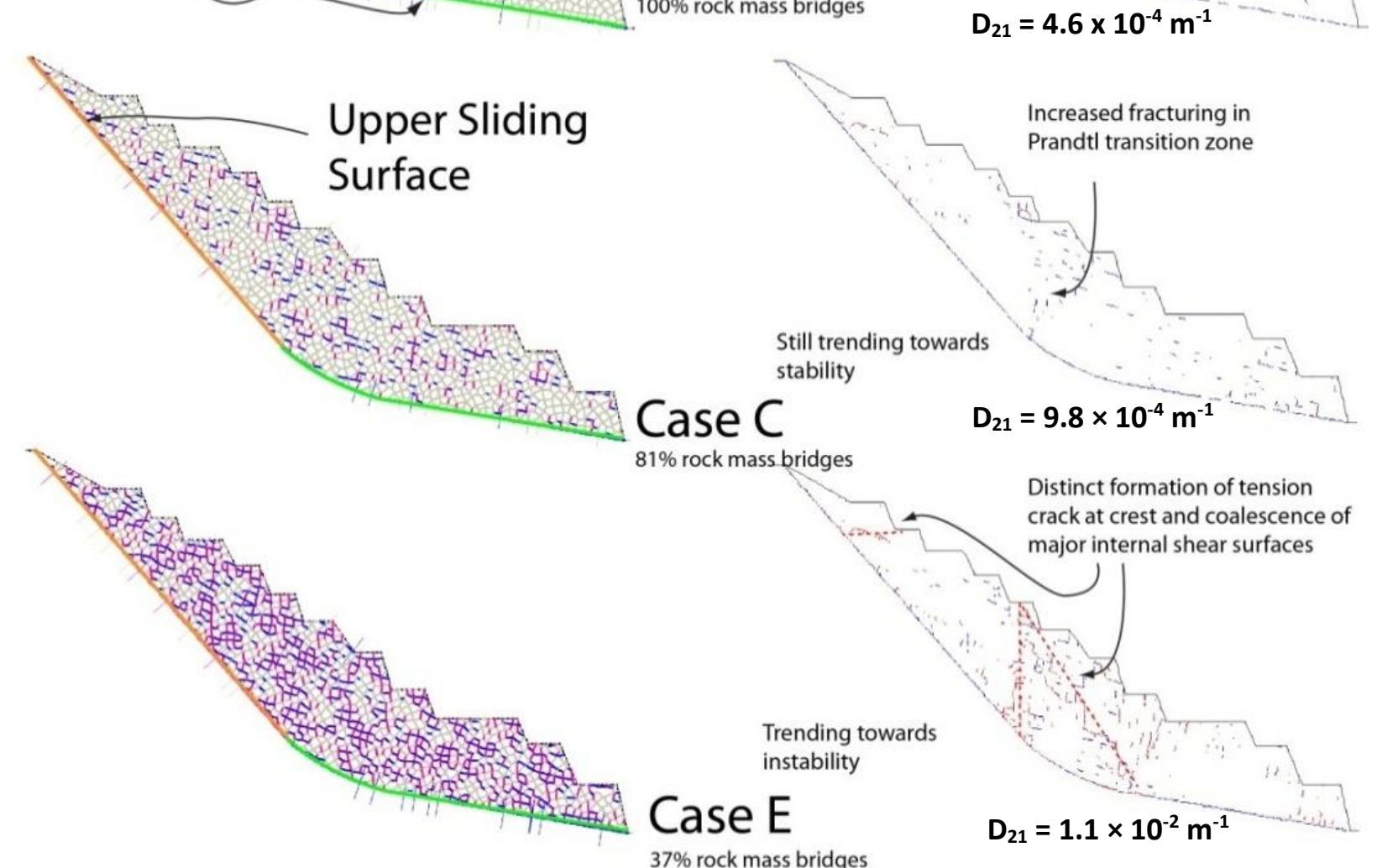

\section{Results}

Minor fracturing,

trending towards stability

$81 \%$ rock mass bridges

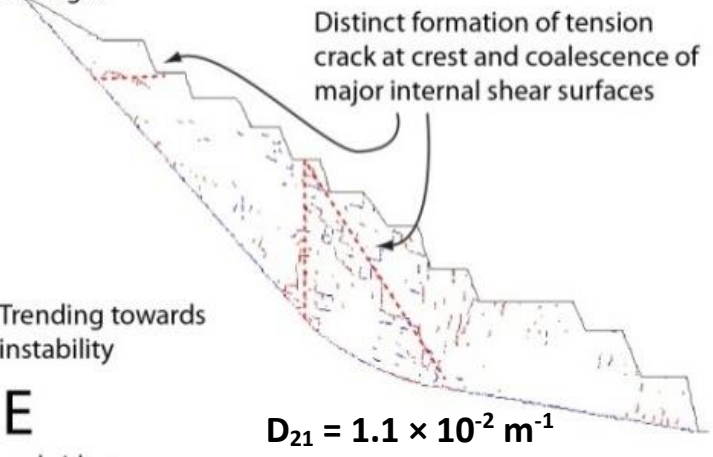

Case $\mathrm{E}$

$37 \%$ rock mass bridges

Figure 9 Three selected distinct element models with identical shear and tensile strength parameters and slope geometry, but varying content of rock mass bridges

Each model case has identical geometry, and the material parameters and joint set contact properties are also identical. However, the content of rock mass bridges was progressively decreased from Case $A$ to $E$, by inserting weak frictional joint properties into the original Voronoi network. The 'rock mass bridge content' was calculated as the length proportion of Voronoi contacts with strong, rock mass properties. Case $A$ therefore considers $100 \%$ rock mass bridges (i.e. all Voronoi contacts are assigned strong, rock mass properties with cohesion $\mathrm{c}=3.5 \mathrm{MPa}$, and tensile strength $\sigma_{t}=3.5 \mathrm{MPa}$, equivalent to $\mathrm{GSI}>90$ ).

The rock mass bridge content is reduced to a minimum of $37 \%$ in Case $E$. The difference between the modelled rock bridge contents (100 to $37 \%$ ) and the published values listed in Table 1 (typically 0 to $10 \%$ ) occurs because this UDEC model considers rock mass bridges - large intervals of $10 \mathrm{~m}$ or more, representing fractured rock mass, which are assigned equivalent rock mass shear strength. In contrast, the 
rock bridge contents listed in Table 1 typically consider true intact rock bridge content, comprising intervals interpreted to consist of unfractured intact rock.

Fracture intensity was measured using the areal intensity approach (trace length divided by surface area), with a damage intensity parameter $D_{21}$ expressed as the total length of broken contacts (i.e. length of new fractures), divided by the cross-sectional area of the sliding rock mass. As rock mass bridge content is decreased from Case $A$ to Case $E$, there is a significant increase in progressive fracturing within the slope. Somewhere between a rock mass bridge content of about $55 \%$ and $80 \%$, at an intermediate condition between Case $C$ and Case $D$, there is a marked increase in the damage intensity $D_{21}$ (Figure 10).

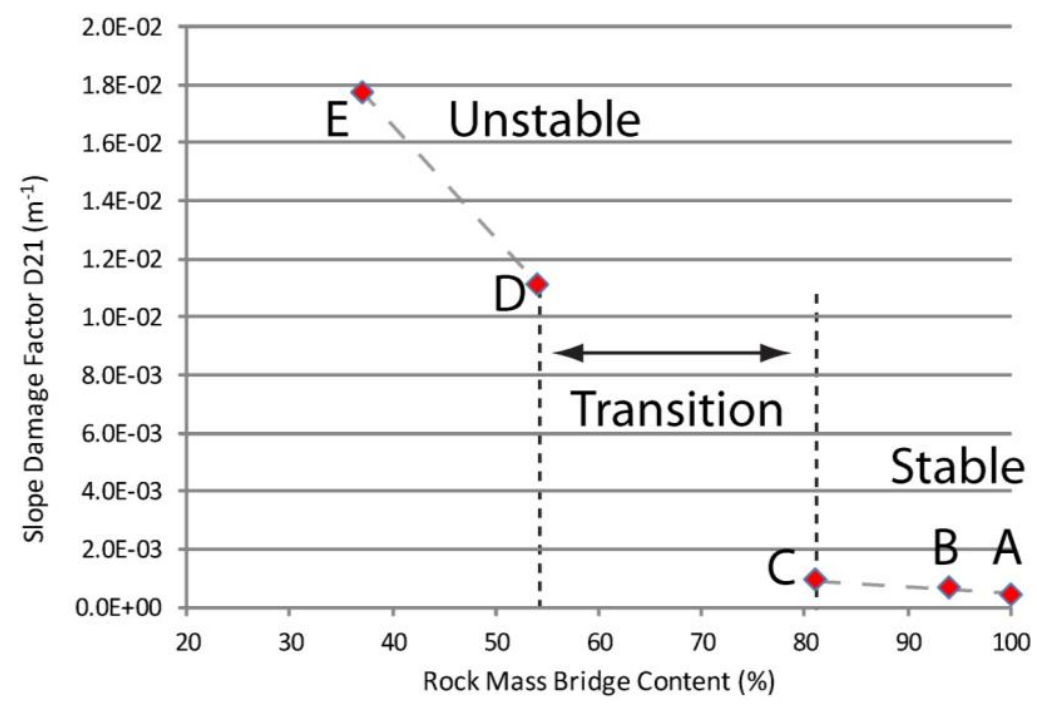

Figure 10 Slope damage intensity D21 for five model cases (A to E), plotted as a function of rock mass bridge content of each case

Although cases $A, B$, and $C$ indicate the development of minor to moderate fracturing within the slope, the displacements measured at the toe of the slope trend towards stability. In contrast, Cases D and $\mathrm{E}$ indicate extensive fracturing throughout the slope, and the displacement versus numerical time does not reach equilibrium, suggesting a trend towards progressive instability.

\section{Preliminary conclusions}

Despite improvements in field mapping technology, it remains difficult to assign a simple numerical quantity to intact rock bridge content and discontinuity persistence inside a large rock slope. Suggested methods for characterising discontinuity persistence and intact rock bridges should begin with traditional structural geology and geotechnical interpretation. The field observations from the three mines indicate that no one set of methods is applicable across all lithological and structural settings. Some rock masses with high GSI may show evidence of 'proto joints' which retain cohesion and tensile strength from intact rock bridges. In some cases slope stability may be mostly controlled by adversely oriented, extremely persistent structures (i.e. $<40 \mathrm{~m}$; Sturzenegger and Stead, 2009). If extremely persistent structures exist, then it is likely that major rock mass bridges, comprising intervals of fractured rock at the scale of metres to tens of metres, may be critical to stability.

The results of a distinct element numerical modelling study illustrate that for large slope failures where dilation may occur, rock (mass) bridges can be an important influence on slope stability, even when they are dispersed throughout the rock mass, rather than occurring exclusively along a basal failure surface. The model of dispersed or 'volumetric rock bridges' may be especially applicable in the case of highly fractured rock masses, or in very large open pit slopes, where jointing can be considered effectively homogenous. Further study is warranted to investigate the utility of parameters for intensity of intact rock bridges, pre-existing discontinuities, and blast-induced fractures in a fracture network engineering approach. When 
coupled with field mapping and stochastic DFN investigations, this approach may help to produce improved quantitative assessments of persistence and intact rock bridge content in large rock slopes.

\section{Acknowledgement}

The authors thank the mining firms and consultants who facilitated the field investigations: Debswana and SRK Consulting; Diavik Diamond Mines Inc. and Golder Associates; Highland Valley Copper and Piteau Associates. Funding for the research was provided through a British Columbia NRAS grant, an FRBC endowment and an NSERC Discovery Grant.

\section{References}

Baczynski, N.R.P. (2000) STEPSIM4 Step-path method for slope risks, in Proceedings International Conference on Geotechnical and Geological Engineering, GeoEng 2000, 19-24 November 2000, Melbourne, Australia, Technomic Publishing, Lancaster, 6 p.

Bahat, D., Rabinovitch, A. and Frid, V. (2005) Tensile fracturing in rocks: Tectonofractographic and electromagnetic radiation methods, Springer, Berlin, $569 \mathrm{p}$.

Bobet, A. and Einstein, H.H. (1998) Fracture coalescence in rock-type materials under uniaxial and biaxial compression. International Journal of Rock Mechanics and Mining Sciences, Elsevier, Vol. 35, pp. 863-888.

Diederichs, M. (1999) Instability of hard rock masses: the role of tensile damage and relaxation, PhD Thesis, Department of Civil Engineering, University of Waterloo, Canada.

Diederichs, M. (2007) The 2003 Canadian Geotechnical Colloquium: Mechanistic interpretation and practical application of damage and spalling prediction criteria for deep tunnelling, Canadian Geotechnical Journal, NRC Research Press, Vol. 44(9), pp. 1082-1116.

Eberhardt, E., Stead, D. and Coggan, J.S. (2004) Numerical analysis of initiation and progressive failure in natural rock slopes-the 1991 Randa rockslide, International Journal of Rock Mechanics and Mining Sciences, Elsevier, Vol. 41, pp. 69-87.

Elmo, D., Yan, M., Stead, D. and Rogers, S.F. (2007) The importance of intact rock bridges in the stability of high rock slopes towards a quantitative investigation using an integrated numerical modelling; discrete fracture network approach, in Proceedings International Symposium on Rock Slope Stability in Open Pit Mining and Civil Engineering (Slope07), Y. Potvin (ed), 12-14 September 2007, Perth, Australia, Australian Centre for Geomechanics, Perth, pp. 253-266.

Elmo, D., Clayton, C., Rogers, S., Beddoes R. and Greer, S. (2011) Numerical simulations of potential rock bridge failure within a naturally fractured rock mass, in Proceedings 2011 International Symposium on Slope Stability in Mining and Civil Engineering (Slope Stability 2011), E. Eberhardt and D. Stead (eds), 18-21 September 2011, Vancouver, Canada, Canadian Rock Mechanics Association, CD-rom only.

Frayssines, M. and Hantz, D. (2006) Failure mechanisms and triggering factors in calcareous cliffs of the subalpine ranges (French Alps), Engineering Geology, Elsevier, Vol. 86(4), pp. 256-270.

Fuji, Y., Takemura, T., Takahashi, M. and Lin, W. (2007) Surface features of uniaxial tensile fractures and their relation to rock anisotropy in Inada granite, International Journal of Rock Mechanics and Mining Sciences, Elsevier, Vol. 44, pp. 98-107.

Gehle, C. and Kutter, H.K. (2003) Breakage and shear behaviour of intermittent rock joints, International Journal of Rock Mechanics and Mining Sciences, Elsevier, Vol. 40, pp. 687-700.

Gischig, V., Amann, F., Moore, J.R., Loew, S., Eisenbeiss, H. and Stempfhuber, W. (2011) Composite rock slope kinematics at the current Randa instability, Switzerland, based on remote sensing and numerical modeling, Engineering Geology, Elsevier, Vol. (118), pp. 37-53.

Grøneng, G., Nilsen, B. and Sandven, R. (2009) Shear strength estimation for Åknes sliding area in western Norway, International Journal of Rock Mechanics and Mining Sciences, Elsevier, Vol. 46, pp. 479-488.

Gudmundsson, A. (2011) Rock Fractures in Geological Processes, Cambridge University Press, Cambridge, UK.

Havaej, M., Stead, D., Lorig, L. and Vivas, J. (2012) Modelling rock bridge failure and brittle fracturing in large open pit rock slopes, in Proceedings 46th US Rock Mechanics/Geomechanics Symposium, 24-27 June, Chicago, USA, American Rock Mechanics Association.

Hencher, S.R., Lee, S.G., Carter, T.G. and Richards, L.R. (2011) Sheet joints: characterization, shear strength and engineering, Rock Mechanics and Rock Engineering, Springer, Vol. 44, pp. 1-22.

Hungr, O. and Amann, F. (2011) Limit equilibrium of asymmetric laterally constrained rockslides, International Journal of Rock Mechanics and Mining Sciences, Elsevier, Vol. 48, pp. 748-758.

ISRM (1978) (International Society for Rock Mechanics) Commission on standardization of laboratory and field tests: Suggested methods for the quantitative description of discontinuities in rock masses, International Journal of Rock Mechanics and Mining Sciences and Geomechanics Abstracts, Elsevier, Vol. 15(6), pp. 319-368.

Itasca (2010) UDEC-Universal Distinct Element Code, Version 5.0, Itasca Consulting Group, Inc., Minneapolis, http://www.itascacg.com/udec.

Jennings, J.E. (1970) A mathematical theory for the calculation of the stability of slopes in open cast mines, in Proceedings Symposium on the Theoretical Background to the Planning of Open Pit Mines, P.W.J. Van Rensburg (ed), 29 August 4 September 1970, Johannesburg, South Africa, South African Institute of Mining and Metallurgy, Cape Town, pp. 87-102. 
Karami, A., Greer, S. and Beddoes, R. (2007) Numerical assessment of step-path failure of northwest wall of A154 Pit, Diavik Diamond Mines, in Proceedings International Symposium on Rock Slope Stability in Open Pit Mining and Civil Engineering (Slope07), Y. Potvin (ed), 12-14 September 2007, Perth, Australia, Australian Centre for Geomechanics, Perth, pp. 293-305.

Kemeny, J. (2005) Time-dependent drift degradation due to the progressive failure of rock bridges along discontinuities, International Journal of Rock Mechanics and Mining Sciences, Elsevier, Vol. 42(1), pp. 35-46.

Lajtai, E.Z. (1969) Strength of discontinuous rocks in direct shear, Geotechnique, Vol. 19(2), pp. 218-233.

LeBaron, A.M. (2011) The effect of rock bridges on blasting fragmentation in sedimentary rock. MSc Thesis, University of Utah, Utah, USA.

Lévy, C., Baillet, L., Jongmans, D., Mourot, P. and Hantz, D. (2010) Dynamic response of the Chamousset rock column (Western Alps, France), Journal of Geophysical Research, American Geophysical Union, Vol. 115, 13 p.

Little, T. (1999) The reliability of blast damaged slopes, in Proceedings of EXPLO '99, C. Workman-Davies (ed), 7-11 November 1999, Kalgoorlie, Australia, Australasian Institute of Mining and Metallurgy, Carlton.

Little, T., Cortes, J. and Baczynski, N. (1999) Risk-Based Slope Design Optimisation Study for the Ok Tedi Copper-Gold Mine, Internal Report to Ok Tedi Mining Limited, dated 30 August 1999, Vol. 1-8.

Mas Ivars, D., Pierce, M.E., Darcel, C., Reyes-Montes, J., Potyondy, D.O., Paul Young, R. and Cundall, P.A. (2011) The synthetic rock mass approach for jointed rock mass modelling, International Journal of Rock Mechanics and Mining Sciences, Elsevier, Vol. 48(2), pp. 219-244.

McMahon, B.K. (1979) Report to Bougainville Copper Limited on Slope Design Studies, Pan Hill, McMahon, Burgess and Yeates, Sydney.

Mencl, V. (1966) Mechanics of landslides with non-circular slip surfaces with special reference to the Vaiont slide, Géotechnique, Vol. 16(4), pp. 329-337.

Moffitt, K., Rogers, S., Beddoes, R. and Greer, S. (2007) Analysis of slope stability in strong, fractured rock at the Diavik diamond mine, NWT, in Proceedings Rock Mechanics: Meeting Society's Challenges and Demands, E. Eberhardt, D. Stead, T. Morrison (eds), 1st Canada-US Rock Mechanics Symposium, Vancouver, Canada, 27-31 May 2007, Taylor \& Francis, pp. 1245-1250.

Ozkaya, S. and Mattner, J. (2003) Fracture connectivity from fracture intersections in borehole image logs, Computers and Geosciences, Elsevier, Vol. 29, pp. 143-153.

Paronuzzi, P. and Serafini, W. (2009) Stress state analysis of a collapsed overhanging rock slab: a case study, Engineering Geology, Elsevier, Vol. 108, pp. 65-75.

Pettitt, W., Pierce, M., Damjanac, B., Hazzard, J., Lorig, L., Fairhurst, C., Sanchez-Nagel, M., Nagel, N., Reyes-Montes, J.M., Andrews, J. and Young, R.P. (2012) Fracture network engineering: combining microseismic imaging and hydrofracture numerical simulations, in Proceedings 2012 American Rock Mechanics/Geomechanics Symposium, June 24-27 2012, Chicago, USA, American Rock Mechanics Association, Alexandria, 9 p.

Priest, S.D. (2004) Determination of discontinuity size distributions from scanline data, Rock Mechanics and Rock Engineering, Springer, Vol. 37(5), pp. 247-386.

Ristau, J. (1994) Field verification of a step-path simulation model for rock slope stability analysis, M.Sc. Thesis, University of Idaho, Moscow, USA.

Sagong, M. and Bobet, A. (2002) Coalescence of multiple flaws in a rock-model material in uniaxial compression, International Journal of Rock Mechanics and Mining Science, Elsevier, Vol. 39, pp. 229-241.

Sainsbury, B., Pierce, M.E. and Mas Ivars, D. (2008) Analysis of caving behaviour using a synthetic rock mass-ubiquitous joint rock mass modelling technique, in Proceedings First Southern Hemisphere International Rock Mechanics Symposium (SHIRMS), Y. Potvin, J. Carter, A. Dyskin, R. Jeffery (eds), Vol. 1 - Mining And Civil, 16-19 September 2008, Perth, Australia, Australian Centre for Geomechanics, Perth, pp. 243-253.

Sjöberg, J. (1999) Analysis of failure mechanisms in high rock slopes, in Proceedings 9 Congrès international de mécanique de roches: Comptes-rendus, G. Vouille and P. Berest (eds), 25-28 August 1999, Paris, France, Balkema, Rotterdam, Vol. 1, pp. 127-130.

Stead, D., Eberhardt, E. and Coggan, J.S. (2006) Developments in the characterization of complex rock slope deformation and failure using numerical modelling techniques, Engineering Geology, Elsevier, Vol. 83, pp. 217-235.

Stead, D., Coggan, J.S., Elmo, D. and Yan, M. (2007) Modelling brittle fracture in rock slopes-experience gained and lessons learned, in Proceedings International Symposium on Rock Slope Stability in Open Pit Mining and Civil Engineering (Slope07), Y. Potvin (ed), 12-14 September 2007, Perth, Australia, Australian Centre for Geomechanics, Perth, pp. 239-251.

Stead, D. and Coggan, J. (2012) Numerical modelling of rock slope instability, in Landslides: types, mechanisms and modelling, J. Clague and D. Stead (eds), Cambridge.

Sturzenegger, M. and Stead, D. (2009) Quantifying discontinuity orientation and persistence on high mountain rock slopes and large landslides using terrestrial remote sensing techniques, Natural Hazards and Earth System Sciences, European Geosciences Union, Vol. 9(2), pp. 267-287.

Sturzenegger, M. and D. Stead, D. (2012) The Palliser rockslide, Canadian Rocky Mountains: characterization and modeling of a stepped failure surface, Geomorphology, Elsevier, Vol. 138, pp. 145-161.

Terzaghi, R.D. (1965) Sources of error in joint surveys, Geotechnique, Vol. 15, pp. 287-304.

Tosney, J.R., Milne, D., Chance, A.V. and Amon, F. (2004) Verification of a large scale slope instability mechanism at Highland Valley Copper, International Journal of Surface Mining, Reclamation and Environment, Taylor \& Francis, Vol. 18(4), pp. 273-288. 
Tunono, A.B., Ruest, M., Dimbungu, L. and Brook, M. (2011) Geotechnical design of the Jwaneng Mine Cut 8, in Proceedings 2011 International Symposium on Slope Stability in Mining and Civil Engineering (Slope Stability 2011), E. Eberhardt and D. Stead (eds), 18-21 September 2011, Vancouver, Canada, Canadian Rock Mechanics Association, CD-rom only.

Van Sint Jan, M.L. and Prudencio, M.G. (2008) The influence of non-persistent joints on the failure modes of large rock slopes, in Proceedings First Southern Hemisphere International Rock Mechanics Symposium (SHIRMS), Y. Potvin, J. Carter, A. Dyskin, R. Jeffery (eds), Vol. 1 - Mining And Civil, 16-19 September 2008, Perth, Australia, Australian Centre for Geomechanics, Perth, pp. 517-527.

Wesseloo, J. and Dight, P.M. (2009) Rock mass damage in hard rock open pit mine slopes, in Proceedings 2009 International Symposium on Slope Stability in Open Pit Mining and Civil Engineering (Slope Stability 2009), 9-11 November 2009, Santiago, Chile, CD-rom only.

Wong, R.H.C., Chau, K.T., Tang, C.A. and Lin, P. (2001) Analysis of crack coalescence in rock-like materials containing three flaws part I: experimental approach, International Journal of Rock Mechanics and Mining Sciences, Elsevier, Vol. 38, pp. 909-924. 